\title{
ひび割れを有するコンクリート中の 鉄筋腐食に関する基礎的研究
}

\author{
塚原 絵万 $^{* 1} \cdot$ 魚本 健人 ${ }^{* 2}$
}

\begin{abstract}
概＼cjkstart要＼cjkstart鉄筋コンクリートは優れた構造部材であるが，コンクリートにひび割れが生じるとひび割れを通じ て腐食因子が容易に鉄筋に到達することとなり, 結果として構造物の性能は著しく低下する。本研究では塩化 物イオンの浸透による鉄筋の腐食を対象とし，ひび割れを有するコンクリート中の鉄筋の腐食を定量的に評価 することを試みた。まずひび割れ部の境界条件を実験的に把握し, 有限要素法を用いた 2 次元拡散解析により ひび割れを通じた塩化物イオンの拡散浸透機構について検討した。次に, 塩化物イオンの濃度差による腐食電 池形成過程をシミュレートし，ひび割れが鋼材腐食に与える影響を検証した。また，環境温度が腐食速度およ び開始時期に与える影響についても併せて検討し，特に塩化物イオンが腐食に及ぼす影響を明らかにした。 キーワード：ひび割れ，塩化物イオン，境界条件，腐食，自然電位，環境温度
\end{abstract}

\section{1.はじめに}

本来，コンクリート構造物は耐久性に優れ，その寿命 は長期間であると考えられていた。しかし，近年，期待 される供用期間中に生じる劣化事例が数多く報告されて おり，社会的にも大きな問題となっている。特にコンク リート中の鋼材腐食は，腐食生成物による体積増加のた めにコンクリートにひび割れを生じさせ，鋼材断面積を 減少させるため, 構造物の性能低下に著しい影響を与え ることが知られている。

コンクリート構造物において, 腐食により生じたひび 割れや，乾燥収縮，アルカリ骨材反応，温度応力等によ り生じたひび割れが早期段階で存在する場合，それらひ び割れからの腐食因子の侵入により鋼材腐食が加速され ることは容易に予測できることであり，早期劣化が問題 となっている今, かぶりコンクリートのひび割れに起因 する鋼材腐食は早急に解決すべき問題と考元る。しかし， 現在までのコンクリート中の鋼材腐食に関する研究は, 腐食程度の経時的な把握に関しては電気化学的測定法を 用いた検討が主であるが, 最終的には供試体破壊後の鋼 材観察に頼る部分が少なくない。また，解析的検討に関 しては，ひび割れ部と健全部との違いを腐食因子に適当 な拡散係数を与えることで表現し，定性的に評価してい るにすぎないのが現状である。

本研究では，塩害環境下に扔ける鉄筋コンクリートを
対象とし, ひび割れを通じた塩化物イオンの浸透機構を 明らかにすることを第一の目的とした。このため，ひび 割れを有する鉄筋コンクリート供試体を用いて，健全部 とひび割れ部の拡散浸透機構の違いを検討した。また， ひび割れ部に打ける境界条件を乾湿繰り返し試験よって 把握し、ひび割れ部に境界条件を与えることの妥当性を 解析により検討した。

また，コンクリート中の鋼材腐食においてひび割れ近 傍の鋼材はアノードを形成することが知られているが, その形成過程をシミュレーションによって再現すること を第二の目的とした。特に，塩化物イオンの拡散に着目 し，塩化物イオン濃度差による濃淡電池作用を考慮した 鋼材腐食モデルを作成した。また，相対湿度や立地条件 等，環境条件は鋼材腐食に大きな影響を及ぼすが，本研 究では塩化物イオンの拡散係数の温度依存性を考慮し, 環境温度の差による腐食開始時期および腐食速度の違い を検討した。

早期劣化現象によって生じるひび割れは，腐食因子の 侵入に多大な影響を及ぼすことは明確であり，主要な腐 食因子である塩化物イオンがマクロセル電池の形成に及 ぼす影響を把握することは，結果として，鉄筋コンクリ 一下構造物の補修箇所, 補修時期の的確な選定を行うた めに必要不可欠である腐食開始時期および腐食速度の予 測に貢献するものと考元る。

*1 東京大学大学院 社会基盤工学専攻（正会員） $\quad \overline{\mathrm{T}}$ 106-8558 東京都港区六本木 7-22-1

*2 東京大学国際・産学共同研究セン多 教授 (正会員) (同 上) 
表一1 コンクリートの配合

\begin{tabular}{|c|c|c|c|c|c|c|}
\hline \multirow{2}{*}{$\begin{array}{c}\text { W/C } \\
(\%)\end{array}$} & \multirow{2}{*}{$\begin{array}{l}\text { s/a } \\
(\%)\end{array}$} & \multicolumn{5}{|c|}{ 単位量 $\left(\mathrm{Kg} / \mathrm{m}^{3}\right)$} \\
\hline & & $\mathrm{W}$ & $\mathrm{C}$ & $S$ & G & $\mathrm{SP}$ \\
\hline 60 & 49 & 161 & 268 & 897 & 974 & $\mathrm{C} \times 0.3 \%$ \\
\hline
\end{tabular}

表ー2 コンクリートの特性

\begin{tabular}{c|c|c|c}
\hline 実験ケース & $\begin{array}{c}\text { スランプ } \\
(\mathrm{cm})\end{array}$ & $\begin{array}{c}\text { 空気量 } \\
(\%)\end{array}$ & $\begin{array}{c}\text { 圧縮強度 } \\
\left(\mathrm{N} / \mathrm{mm}^{2}\right)\end{array}$ \\
\hline $20^{\circ} \mathrm{C}-13$ 週用 & 6.1 & 4 & 31.7 \\
\hline $40^{\circ} \mathrm{C}-13$ 週用 & 6.8 & 4.8 & 26.7 \\
\hline 4 週用 & 9.6 & 5.8 & 33.6 \\
\hline
\end{tabular}

表一3 鋼材の化学成分

\begin{tabular}{c|c|c|c|c|c}
\hline $\mathrm{Fe}$ & $\mathrm{C}$ & $\mathrm{Si}$ & $\mathrm{Mn}$ & $\mathrm{P}$ & $\mathrm{S}$ \\
\hline 99.6 & 0.19 & 0.12 & 0.53 & 0.033 & 0.037 \\
\hline
\end{tabular}

\section{2. 実験概要}

\section{1 使用材料および配合}

本研究において用いたコンクリートの示方配合を表一 1 に，またコンクリートの物性を表一2示す。鉄筋は SD295Aの異型鉄筋をアセトン脱脂後，黒皮付きのまま 使用した。化学成分を表一 3 に示す。

\section{2 供試体の作成}

$10 \times 10 \times 40 \mathrm{~cm}$ の型枠内にコンクリートを打設し， 24 時間後脱型して材齢 28 日まで温度 $20^{\circ} \mathrm{C}$ で水中養生を行 った。鉄筋は純かぶりで $20 \mathrm{~mm}$ となるよう供試体の中心 に配置した。その後，3点曲げ載荷により供試体下面の 中央付近に曲げひび割れを設けた。除荷後, ひび割れ幅, および供試体両側面より目視範囲内のひび割れ深さを測 定し，ひび割れ開口面 (以降, 開方面と呼ぶ) を除く 5 面をエポキシ系樹脂により被覆し, 腐食物質は 1 面のみ から侵入するようにした。なお，ひび割れ幅は開放面に おけるひび割れ幅 7 点の平均值であり，ひび割れ深さは 供試体両側面から測定した目視範囲内のひび割れ梁さの 平均值であるとした。比較用の載荷を行わない供試体に ついても同様に被覆を行った。供試体の形状を図ー1に 示す。鉄筋両端部は自己癒着テープを用いて防水し，端 部からの腐食開始を防いだ。

\section{3 促進試験方法}

促進試験は供試体材齢 35 日から行い, 3 日間の乾燥 および模擬海水中への浸漬 4 日間を 1 サイクルとする乾 湿繰り返し実験を $20^{\circ} \mathrm{C} \cdot 40^{\circ} \mathrm{C}$ 供試体については 13 サイ クル, $50{ }^{\circ} \mathrm{C} \cdot 60^{\circ} \mathrm{C} \cdot 80^{\circ} \mathrm{C}$ 供試体については 4 サイクル 行った。模擬海水の温度, 乾燥時の環境温度は常時一定 となるよう設定した。模擬海水は濃度 $3 \pm 0.3 \%$ の塩化 ナトリウム水溶液であり, 乾燥時の相対湿度は $60 \%$ と

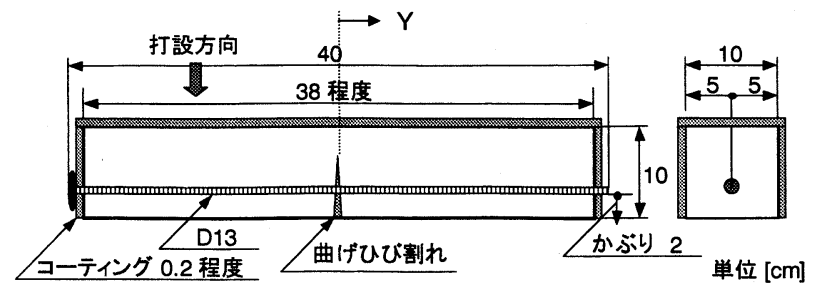

図-1 供試体概要

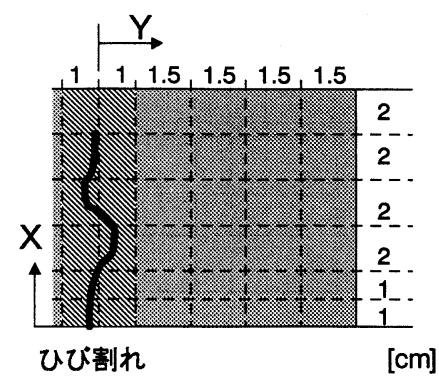

図一2 資料の採取

した。

\section{4 全塩化物量測定方法}

測定試料は，供試体を割裂し鉄筋を取り除いた後， 図ー2に示すようにひび割れを中心とする領域（ひび割 れ部：図 -2 幅 $10 \mathrm{~mm} \times 2$ ） から左右両方向にオイルカ ッターで切出して作成した。測定試料の奥行きは約 5 $\mathrm{cm}$ である。なお，ひび割れのない供試体については供 試体中央部分を同様に切出して作成した。JCI-SC4およ びSC $5^{11}$ を参考にして粉体試料から測定試料を作成し， 簡易塩分分析計（東亜電波工業製）を用いてセメント中 に含まれる全塩化物イオン量の測定を行った。

\section{5 腐食程度の把握}

促進試験開始時から 1 サイクル毎に浸漬期間終了後, 自然電位の測定を開放面より行った。用いた照合電極は 銀塩化銀電極である。しかし，自然電位に基づく劣化診 断は，測定時の腐食進行度を示す定性的なものに過ぎな い。従って, 小山 ${ }^{2)}$ の研究を参考にして自然電位の変曲 点を電流量解析により求め, 鋼材のアノード領域とカソ 一ド領域の境界を把握し, 電流量の積算值より腐食反応 量を推定した。まず，電位と電流量の関係はオームの法 則に従うので，以下の式により電流量分布を推定する。

$$
I_{k}=\int_{0}^{L} i_{k x} d x=\frac{V_{k x}}{R_{k}} d x
$$

ここに, L : 鉄筋長 $(\mathrm{cm})$

$\mathrm{I}_{\mathrm{k}}$ : 任意の点 $\mathrm{k}$ に流れ込む総電流量 $(\mathrm{A} / \mathrm{cm})$

$\mathrm{i}_{\mathrm{kx}}$ : 点 $\mathrm{k}$ に各点 $\mathrm{x}$ から流れ込む電流密度 $\left(\mathrm{A} / \mathrm{cm}^{2}\right)$

$\mathrm{V}_{\mathrm{kx}}$ ：点 $\mathrm{k}$ と各点 $\mathrm{x}$ の単位長さあたりの電位差 $(\mathrm{V} / \mathrm{cm})$

$\mathrm{R}_{\mathrm{k}}$ ：点kにおけるコンクリートの比抵抗 $(\mathrm{k} \Omega \cdot \mathrm{cm})$

本研究では，一般的なコンクリートの比抵抗值を参考 


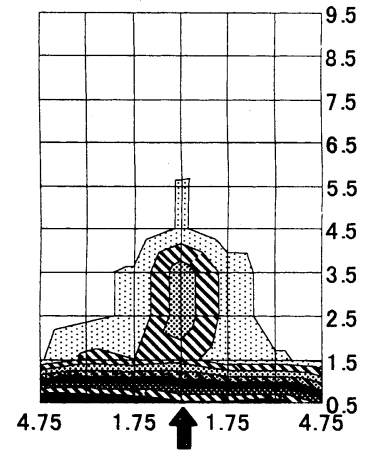

$20^{\circ} \mathrm{C}$-ひび割れ幅 $0.10 \mathrm{~mm}$ ひひ割れ深さ $70 \mathrm{~mm}$

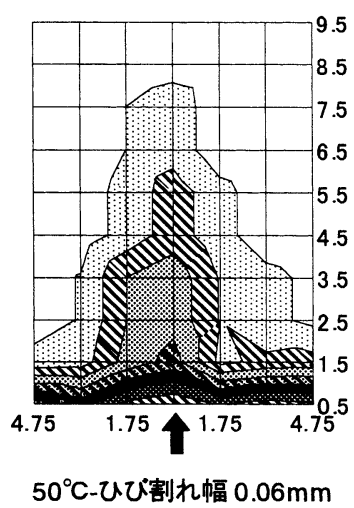

ひび割れ深さ $47 \mathrm{~mm}$

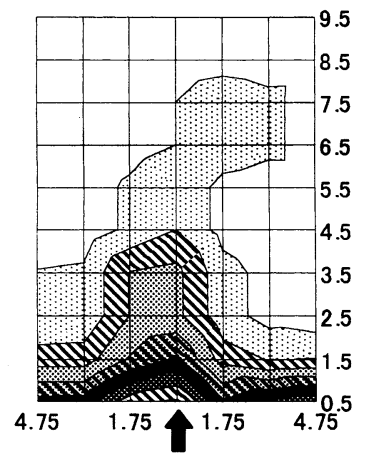

$40^{\circ} \mathrm{C}$-ひび割れ幅 $0.07 \mathrm{~mm}$ ひび割れ深さ $63 \mathrm{~mm}$

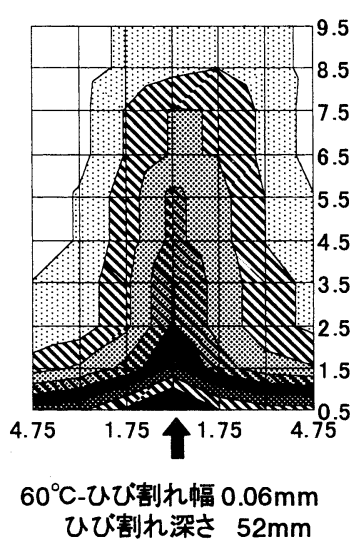

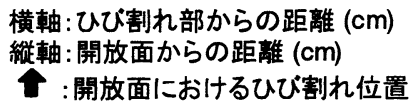

全塩化物イオン量 (\% by wt. of cement)

<凡例> $\square$ 0-0.4 0.4-0.8

$\$ 0.8-1.2 * 1.2-1.6$

1.6-2 $\square 2-2.4$

2.4-2.8 2.8-3.2

$\square 3.2-3.6 \square 3.6-4$

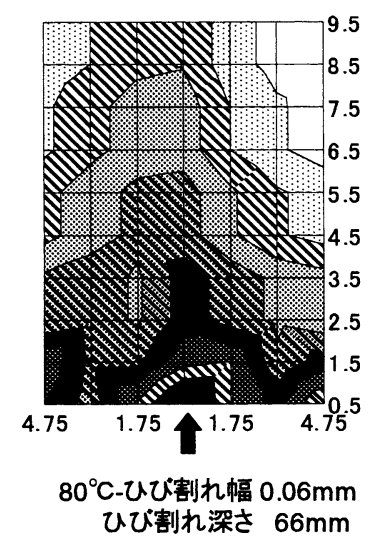

図一3 塩化物イオン濃度分布（促進 4 週間 実測值）

にして，コンクリート中で $10 \mathrm{k} \Omega$ 一定と設定した。式 (1) から鉄筋表面各点における電流密度が推定され，こ れに測定時間を乗じることにより積算電流量が算出され る。式 ( 2 )に示すファラデーの法則より, 腐食量と積算 電流量が比例関係となり，任意の時間 $\mathrm{t}$ における腐食反 応量を積算電流量から予測できると考えられる。

$$
W_{k}=\int_{0}^{t} k I(t) d t
$$

ここに， $\mathrm{W}_{\mathrm{k}}$ : 腐食反応量 $(\mathrm{g} / \mathrm{sec})$

$$
\mathrm{k} \text { : 電気化学当量 }(\mathrm{g} / \mathrm{A} / \mathrm{sec})
$$

この手法により，自然電位の経時的な測定結果から電 気化学的な理論を用いて腐食の進行状態を把握できるよ うになる。

供試体割裂後, 鉄筋の発錆範囲を写し取り, 画像解析 にて腐食面積を測定した。

\section{3. 塩化物イオンの拡散浸透}

\section{1 塩化物イオンの浸透状況}

図一3に各環境温度下における促進 4 週時のひび割れ 周辺部の塩化物イオン濃度分布を示す。これは図 -2 に 示した測定位置における塩分濃度を等高線にて表したも のであり，図中の矢印は開放面におけるひび割れ位置の
中心，すなわちひび割れ部の中心を示している。図－3 よりひび割れを有するコンクリートは内奥部まで塩化物 イオンが浸透しやすくなっていることは明らかであり， ひび割れを中心として塩化物イオンの濃度分布が形成さ れていることが分かる。また，環境温度が高いものほど その浸透量は多くなっており, 塩化物イオンの拡散に環 境温度が多大な影響を与えていることが予測される。こ れらの現象を把握するために, 次節より塩化物イオン拡 散性状の温度依存性, およびひび割れの存在が塩化物イ オン拡散性状に及ぼす影響を検討した。

\section{2 塩化物イオン拡散の温度依存性}

塩分の浸透現象は，コンクリート中の細孔における水 分の浸透に伴う移動, 濃度拡散, および化学的固定 - 吸 着等が複雑に絡み合った現象である。特に, 湿繰り返し 環境下ではコンクリート中の水分移動が激しいことが考 えられ例济3，浸透現象を濃度拡散のみで把握することは 適当とはいえない。しかし, 塩分量実測データにFick の第 2 法則として知られている拡散方程式を当てはめ, 表面塩分量に相当する境界条件を一定とすることにより 近似が可能となる。本研究で扱う拡散現象とは, 以降見 かけの拡散を示すものとする。

本研究では丸屋 ${ }^{4)}$ にない, 表面塩分量は試験期間の 平方根に比例すると仮定し，次式のように表した。

$$
\mathrm{C}_{0}=\mathrm{C}(0, \mathrm{t})=\mathrm{S} \sqrt{\mathrm{t}}
$$




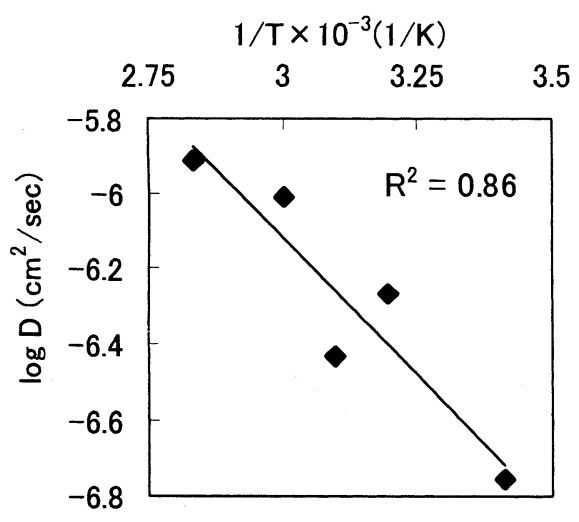

図-4 塩化物イオン拡散係数のアレニウスプロット (促進 4 週)

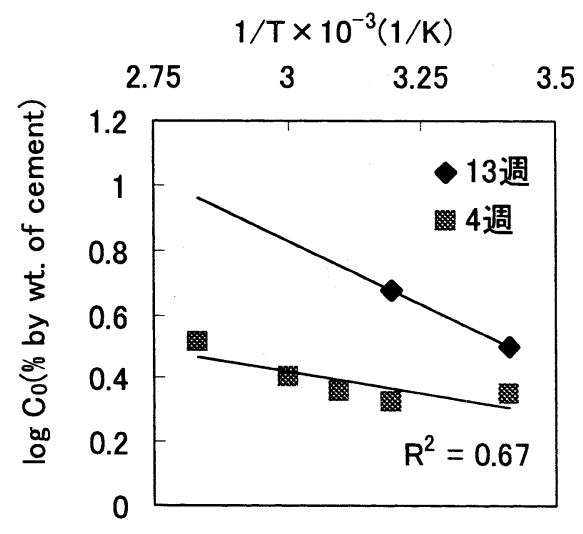

図－5＼cjkstart表面塩分量のアレニウスプロット

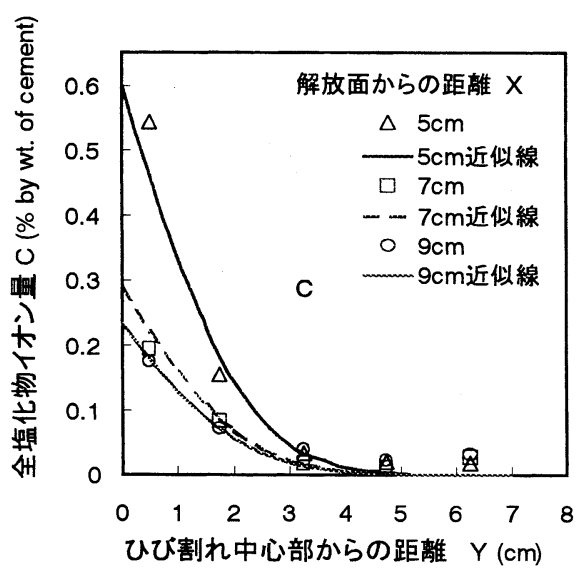

図一6 塩化物イオン量実測データの近似

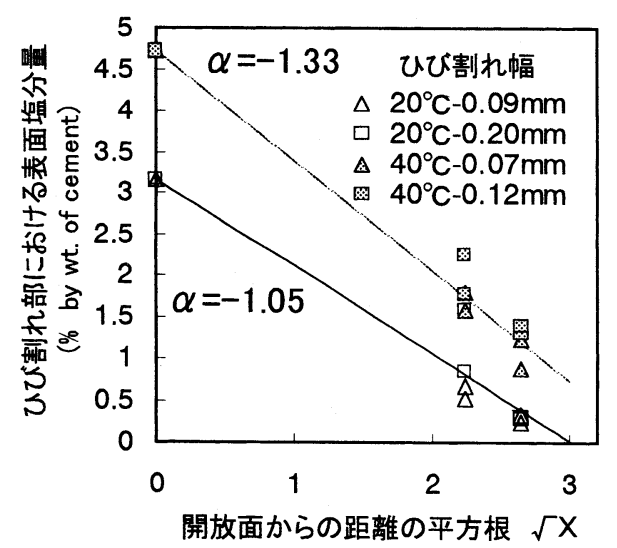

図-7 解放面からの距離と表面塩分量との関係
ここに，Co：表面塩分量（wt.\%）

$\mathrm{S}$ : 表面塩分量係数 $(1 / \sqrt{ } \mathrm{sec})$

$\mathrm{t} ：$ 拡散が生じてからの時間 $(\mathrm{sec})$

式 ( 3 ) および初期条件 C $(\mathrm{x}, 0)=0$ のもとでFickの拡 散方程式を解くと, 解は次式 (4)のようになる。

$$
\begin{aligned}
\mathrm{C}(\mathrm{x}, \mathrm{t})=\mathrm{S} \sqrt{\mathrm{t}}\left\{\exp \left(-\frac{\mathrm{x}^{2}}{4 \mathrm{Dt}}\right)-\frac{\mathrm{x} \sqrt{\pi}}{2 \sqrt{\mathrm{Dt}}} \operatorname{erfc} \frac{\mathrm{x}}{2 \sqrt{\mathrm{Dt}}}\right\}(4) \\
\text { ここに, } \mathrm{C} \text { : 塩化物イオン量 }(\mathrm{wt} . \%) \\
\mathrm{x} \text { : 表面からの距離 }(\mathrm{cm}) \\
\mathrm{D} \text { : 見かけの塩化物イオン拡散係数 }\left(\mathrm{cm}^{2} / \mathrm{sec}\right)
\end{aligned}
$$

勝木 ${ }^{5}$ は $\mathrm{Na}^{+}$拡散係数の温度依存性をアレニウス式を 用いることにより評価し，GFRPロッドの強度低下を予 測している。これを参考にし，式(4)より得られた各環 境温度下におけるひび割れの無い供試体の塩化物イオン 拡散係数のアレニウスプロットを図ー4に示す。塩化物 イオン拡散係数と環境温度は良好な関係を示しており, アレニウス式を用いることにより一定の乾湿繰り返し環 境下における環境温度の影響を予測することが可能であ ると考えられる。これは次式のように表すことができ る。

$$
\mathrm{D}=\mathrm{e}^{\mathrm{A} / \mathrm{T}}
$$

\section{ここに，A：暴露環境に関する係数 $\mathrm{T}$ ：環境温度（絶対温度，K）}

図一 5 は，拡散係数と同様にひび割れの無い供試体の 塩分量実測值を用いて求めた各試験期間における表面塩 分量 $\mathrm{C}_{0}(\mathrm{x}=0, \mathrm{t}=4$ or 13 週 $)$ のアレニウスプロット である。本研究の範囲内においては, 表面塩分量も拡散 係数と同様に温度依存性を有し，供試体が一定環境下に ある場合，式（5）の様に時間と環境温度の関数として表 すことが可能であると考えられる。

\section{3 ひび割れからの塩化物イオンの拡散浸透}

かぶりコンクリート中を浸透することと比較して，ひ び割れを通じることにより塩化物イオンの浸透が容易に なると考えると，ひび割れ部は開放面とは異なった境界 条件を持つことが考えられる。

図ー6に13週を経たひび割れ周辺の塩化物イオン量 実測デー夕と式 (4)より求めた近似線の一例を示す（環 境温度 $20^{\circ} \mathrm{C}$, 表面ひび割れ幅 $\left.0.09 \mathrm{~mm}\right) 。$ 図中の Xはひ び割れ梁さ方向，Yはひび割れに対して垂直方向を示す (図一2参照)。ここで，かぶりコンクリートにおいては 開放面からのX方向への浸透が考えられ，鉄筋位置にお いては周辺の微細なクラックによる塩化物イオンの蓄積 の影響が考えられる。従って，X=4〜10cmまでの測 定結果をひび割れ部分からの浸透と見なすこととした。 
ひび割れ部は微少領域であり, 近似の際, 塩化物イオン 拡散係数はひび割れの無い供試体と等しいとしても差し 支えないと考えられるため, 同一環境温度における拡散 係数をそれぞれ用いた。図一6より塩分量実測データに 対する式(4)による近似は良いことが分かる。これより， 拡散係数を同じ環境温度におけるひび割れの無い供試体 と同一とした近似は妥当であり，ひび割れ部の表面塩分 量は内奥部に向かうほど小さくなることが分かる。

図ー7に各ひび割れ供試体における開放面からの距離 とひび割れ部の表面塩分量との関係を示す。ひび割れ部 の表面塩分量は開放面からの距離の平方根と良い相関を 示し，式(6)の様に表すことができる。

$$
\mathrm{C}_{\mathrm{c}}(\mathrm{x}, \mathrm{t})=\alpha \sqrt{\mathrm{x}}+\mathrm{S} \sqrt{\mathrm{t}}
$$

ここに， $\alpha$ : 境界条件である表面塩分量のひび割れ内奥 方向への減衰を表す係数

(ひび割れ有り $\neq 0$ ，なし $=0$ )

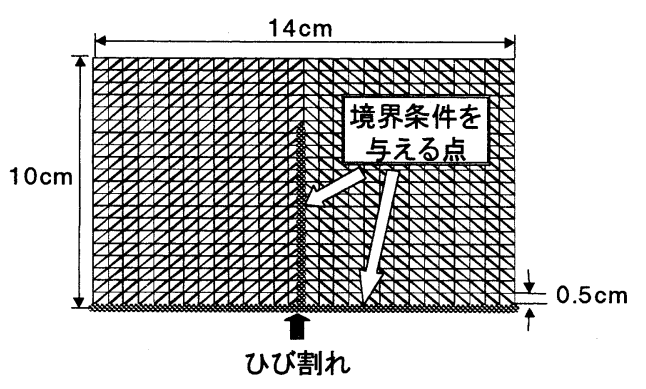

図一8 解析モデル
$\mathrm{C}_{\mathrm{c}}$ ：開放面から $\mathrm{Xcm}$ の距離のひび割れ部にお ける表面塩分量（\%)

図－7より明らかなように，本実験の範囲内では，係 数 $\alpha$ はひび割れ幅よりも環境温度の影響を受けやすい係 数と考えることができる。

式 (6)に示したひび割れ部における境界条件の妥当性 を検討するため, 有限要素法を用いて 2 次元拡散解析を 行った。図一8に解析モデルを示す。境界条件は開放面

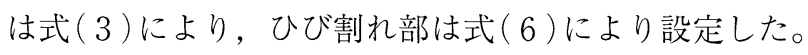
ひび割れ部は供試体側面から測定したひび割れ深さを参 考にし， $6.5 \mathrm{~cm}$ と設定した。ここでは環境温度 $20^{\circ} \mathrm{C}$ の場 合を対象とし, 塩化物イオン拡散係数, 表面塩分量係数 ともに実験より得られた数值を用いた。塩化物イオン拡 散係数は $1.83 \times 10^{-7} \mathrm{~cm}^{2} / \mathrm{sec}$, 表面塩分量係数は $1.1 \times$ $10^{-3}$ である。

図ー9にひび割れ幅 $0.09 \mathrm{~mm}$ 供試体における全塩化物 イオン量の実測データと, 拡散解析より得られた塩化物 イオンの分布を示す。解析值と実験值はほぼ一致してお り，表面塩分量を時間の関数として表すこと，およびひ び割れ深さ方向の境界条件に減衰を与えることで, 塩化 物イオン分布を推測することが可能となることが分か る。本研究の範囲では, $0.07 \sim 0.20 \mathrm{~mm}$ 程度のひび割れ 幅の違いは塩化物イオンの拡散浸透に大きく影響しなか った。さらに精度の良い分布予測を目指すためには，ひ び割れ幅よりもひび割れ深さの把握が必要と考えられ る。

\section{全塩化物イオン量（\% by wt. of cement）}
$\square 0-0.2$
0.2-0.4
$\square 0.4-0.6$
0.6-0.8 $\square 0.8-1$
$1-1.2$
1.2-1.4
$1.4-1.6$

1.6-1.8 $\square 1.8-2 \quad \square 2-2.2$

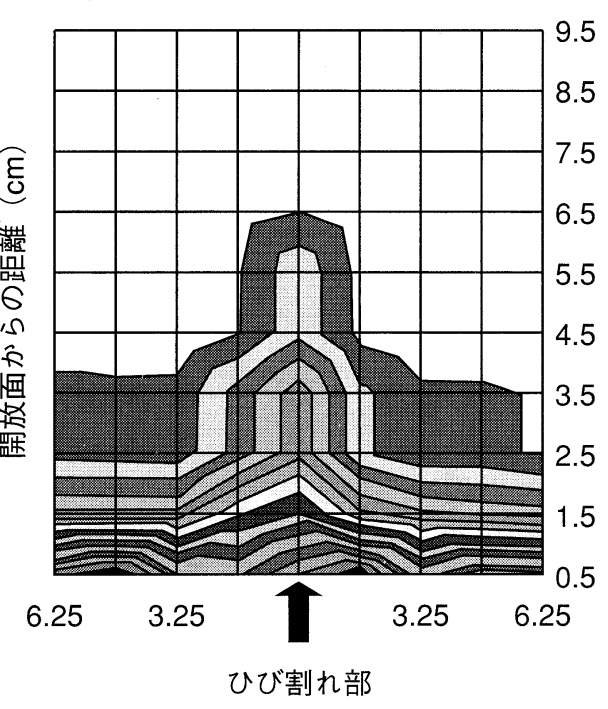

ひび割れ部からの距離 $(\mathrm{cm})$

$\left(20^{\circ} \mathrm{C}\right.$-ひび割れ幅 $0.09 \mathrm{~mm}$ 実測值 $)$

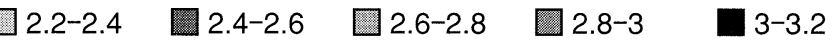

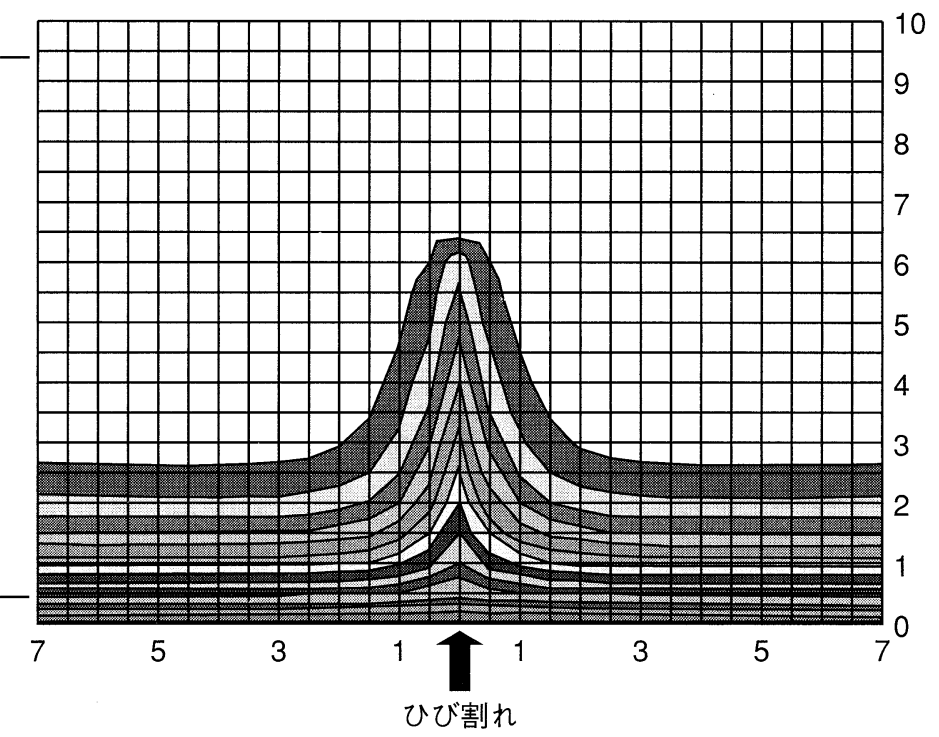

ひび割れ部からの距離 $(\mathrm{cm})$

(解析值) 

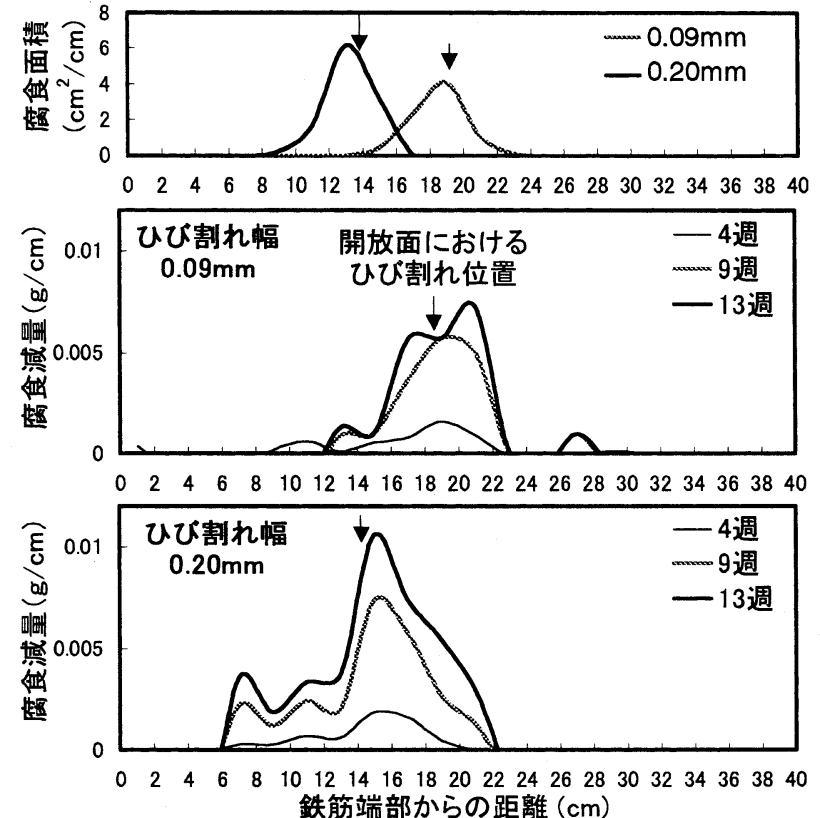

図-10 腐食面積と腐食減量の経時変化（環境温度 $20^{\circ} \mathrm{C}$ )

4.ひび割れを有するコンクリート中の鋼材腐食

\section{1 ひび割れ周辺の腐食性状}

まず，期間 13 週の乾湿繰り返し実験供試体から得ら れたひび割れ周辺部の鋼材腐食性状について検討する。 1 サイクル毎の自然電位の測定より電流量解析を用いて 得られた環境温度 $20^{\circ} \mathrm{C}$ 供試体の腐食減量の経時変化と, 13 週供試体に扔ける腐食面積を図一 10 に示す。な挹, 図中の矢印は開放面におけるひび割れの中心を示してい る。図ー 10 より供試体割裂後に測定した腐食面積と自 然電位から予測した腐食減量との位置はほぼ同一であ り，腐食反応はひび割れを中心とした周辺において起こ ったことが分かる。

ここで，初期のひび割れ部の腐食促進について考察す る。ひび割れが大きい場合などコンクリート中の鉄筋の 一部がコンクリートで被覆されない裸鋼として存在する ときには，裸鋼部と被覆鋼部との間に活性一不動態電池 と呼ばれるマクロセル腐食電池が形成される。この電池 では裸鋼部がアノード，被覆鋼部がカソードとなり，大 きな電位差が生じるので，裸鋼部の鉄筋の腐食が著しく 促進される。また，ひび割れが存在することによってコ ンクリート中における塩化物イオン濃度の差が極端に生 じ，濃淡電池作用が働くことが考えられる。図一10に おいて腐食領域はひび割れ位置だけでなく軸方向にも広 がっているが，これは鉄筋下面の脆弱層および曲げ載荷 時に多数発生した内部ひび割れによって，塩化物イオン およびその他の腐食因子が浸透し易くなったためと考え られる。森永 ${ }^{61}$ は，塩分を混入したペースト中の鉄筋の 腐食実験で，腐食速度は湿度の大きく影響され，湿度が $80 \%$ のときに腐食速度がピークに達するという結果を

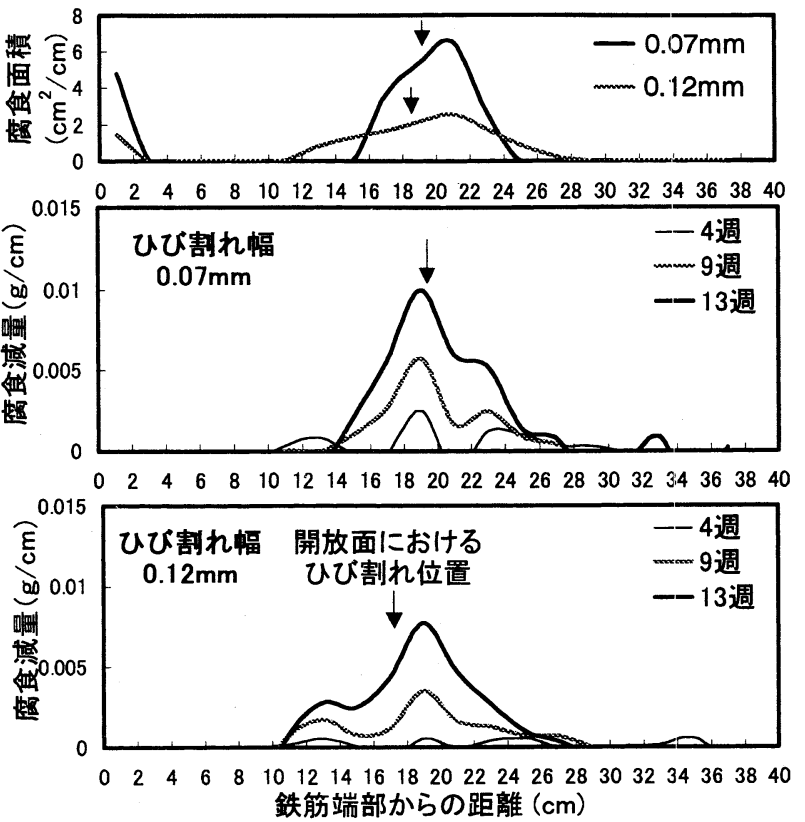

図-11 腐食面積と腐食減量の経時变化（環境温度 $40^{\circ} \mathrm{C}$ )

得ているが，このことは塩化物イオンが存在するコンク リート中でも対応し，部分的な湿度と酵素供給のバラン スによってひび割れ近傍の鉄筋の腐食速度が高まったと 考えることができる。

ひび割れ部のみでなく，ひび割れ周辺部においても不 動態被膜の破壊を生じさせるに十分な量の塩化物イオン が浸透すると，鉄筋はアノードと成りえる。この時，酸 素の透過量は健全はコンクリート内部の鋼材と比較し て，ひび割れ周辺部の鉄筋で無論多くなる。すなわち， 多量の酸素が到達するひび割れ周辺部の鉄筋がマクロセ ルのカソードになり易く成る状況が考えられる。マクロ セルはアノードとカソード間の電気抵抗が小さいほど形 成が容易となるため，ひび割れ周辺部の鉄筋がアノード となるマクロセルの形成は十分考えられる。促進期間の 増加に伴う腐食減量増加の低減は，ひび割れ部がアノー ドからカソードに移行する途中段階での現象と考えら れ，これは長期暴露と短期暴露においてマクロセルの形

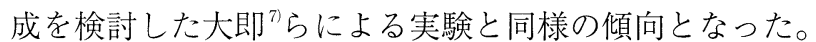
その他の要因としては, 腐食生成物によって反応が妨げ られたことが挙げられる。

$20{ }^{\circ} \mathrm{C}$ 供試体と同様に求めた環境温度 $40{ }^{\circ} \mathrm{C}$ 供試体の腐 食減量の経時変化と 13 週供試体における腐食面積を 図ー11に示す。腐食はひび割れ周辺部においで起こっ ており，自然電位の経時変化を用いた電流量解析によっ て，非破壊的に鋼材の腐食が把握できることが分かる。 本研究の範囲内では，3章に示した塩化物イオンの拡散 と同様に，ひび割れ幅による腐食性状の差異は明確には 見られなかった。しかし, 腐食減量の経時変化は環境温 度によって異なった傾向を示しており, 促進期間 4 週か ら 9 週における腐食減量, 即ち積算電流量の増加に明ら 


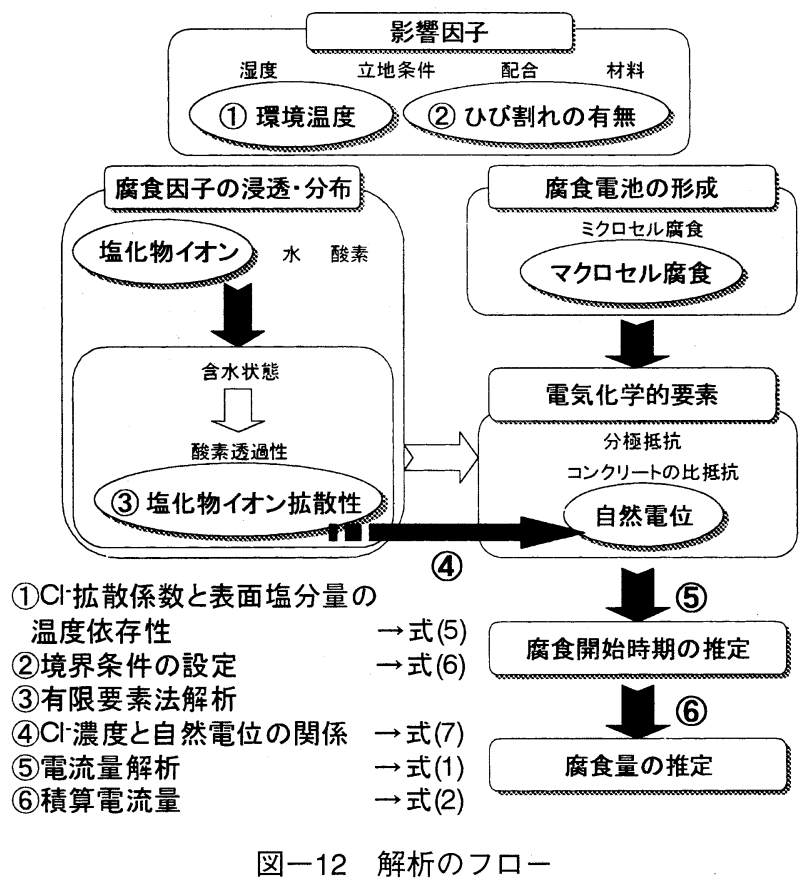

かに違いが見られる。そこで，次節に示す解析モデルを 用いて，ひび割れを有するコンクリート中の腐食性状， および環境温度が腐食性状に及ぼす影響を検討した。

\section{2 解析モデル}

本研究では, 特にひび割れ周囲の塩化物イオンの拡散 浸透に着目し，それがひび割れ周辺の鋼材腐食に及ぼす 影響を検討した。

腐食シミュレーションにおいては，図一12に示すフ ローが考えられるが，本研究では太字扔よび黒矢印で表 される現象を重視し解析を行った。図に示すように環境 温度の影響は塩化物イオン拡散係数と表面塩分量に，ま た，ひび割れの影響は境界条件の設定法に反映される。 解析においては酸素拉よび水の供給とそのバランス，ま た腐食生成物による腐食因子の遮蔽効果は考慮されてい ない。解析は前章と同様のモデル（図－8）を用いて行 い，鉄筋は開放面から $2 \mathrm{~cm}$ の位置に存在すると設定し た。鉄筋位置に扔ける塩化物イオン濃度差により起電力 が生じるとして，特に塩化物イオンの拡散に注目した腐 食現象の再現を試みた。

一般に, Fickの拡散方程式を用いる場合, 拡散係数 は時間に依存しない定数として扱われる。しかし，コン クリートの塩化物イオン拡散係数抢よび表面塩分量は時 間に依存する傾向にあることが指摘されている畞え゙88,99 これは, 継続すれセメントの水和反応やポゾラン反応に よって毛細血管空隙の径㧍よび連続性が低下し，塩化物 イオンの拡散に対する抵抗性が増加するためと考察され ている。しかし, 本研究では期間 13 週の促進試験より 求めた数值を用い, 拡散係数は変化せず常に一定の值と し，表面塩分量は実際の試験期間以降は増加しないと設 定して解析を行った。

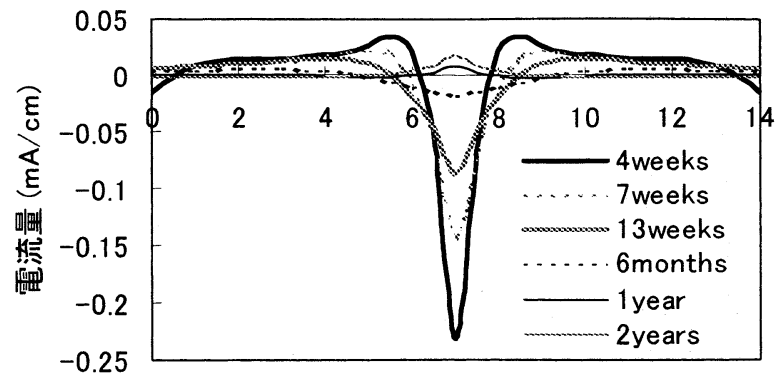

モデル鉄筋端部からの距離 $(\mathrm{cm})$

図-13 電流量分布 (環境温度 $20^{\circ} \mathrm{C}$ 解析值)

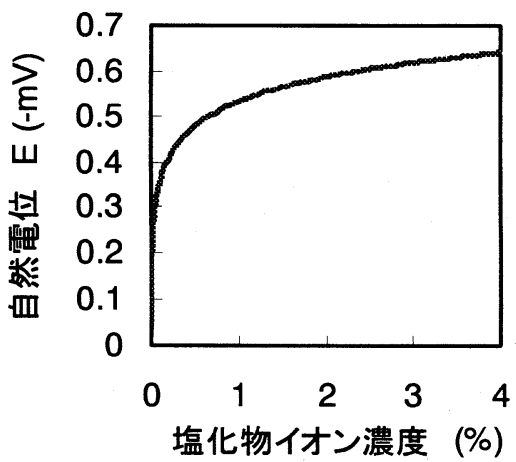

図一14 自然電位と塩化物イオン濃度の関係

塩分濃度と自然電位の関係はよい相関を持ち, 塩分量 が多いほど電位は卑な值となるといわれている。自然電 位の差はマクロセル腐食の起電力に相当するものであ り，その変化量は腐食に直接関係するパラメータと考え られる。そこで，次式 ${ }^{10} を$ 用いて各位置における自然電 位 $\mathrm{E}$ 求めた。

乾燥条件下: $\mathrm{E}=0.070806 \mathrm{Ln}(\mathrm{NaCl})-0.34122$

湿潤条件下 $: \mathrm{E}=0.087283 \mathrm{Ln}(\mathrm{NaCl})-0.62419$

(vs CSE)

ここに, $\mathrm{E}:$ 電位 $(\mathrm{V})$

$\mathrm{NaCl}$ ：コンクリートに対する塩分 $(\mathrm{NaCl})$ の重量\% 濃度

自然電位にはその他に特に含水率が影響するが，式 （7）には単純な環境区別のみしか表されていない。従っ て,コンクリートは常に両者の中間的な湿潤状態にある と仮定し，鉄筋の自然電位は両者の平均值であるとして 解析に用いた。解析により得られた自然電位は, 実験值 と同様に $2.5 に$ に示した電流量解析を行った。

\section{3 ひび割れ部における鉄筋腐食の解析的検討}

図一 13 に $20^{\circ} \mathrm{C}$ 供試体から得られた拡散係数, 表面塩 分量係数㧍よび係数 $\alpha$ を使用し,ひび割れ幅 $0.09 \mathrm{~mm}$ の 供試体を参考にし，ひび割れ深さを 3 章と同様に設定し た解析から得られた各期間毎の電流量の分布を示す。電 流量はマイナス側がアノード，プラス側がカソードを示 すが，ひび割れ部の電流量は28日以降，次第にカソー ド側に近づいていく結果となった。同時に，ひび割れか 
28日

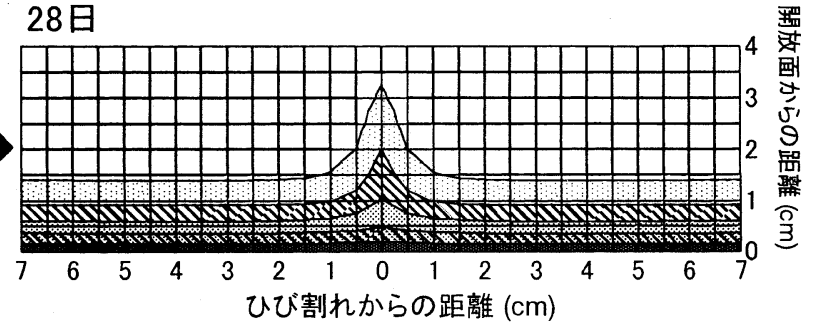

全塩化物イオン量 (\% by wt of cement) 口0-0.4 国 0.4-0.8 \$0.8-1.2 网 1.2-1.6

1.6-2 2-2.4 2.4-2.8 $\mathbf{2 . 8 - 3 . 2}$

図一15 塩化物イオン濃度分布 (環境温度 $20^{\circ} \mathrm{C}$ 解析值)

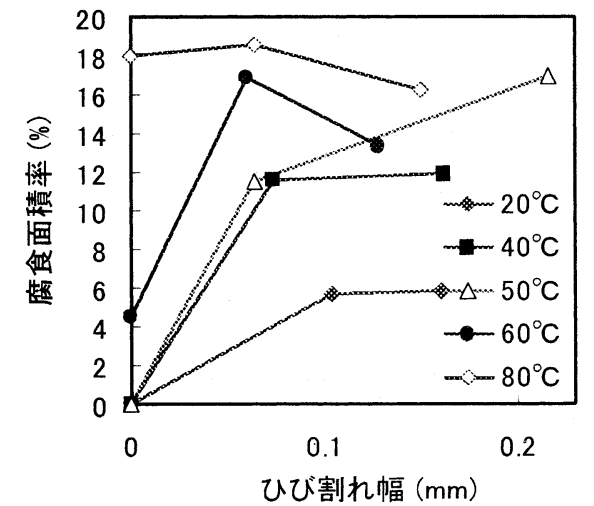

図-16 腐食面積率（試験期間 4 週 実測値）

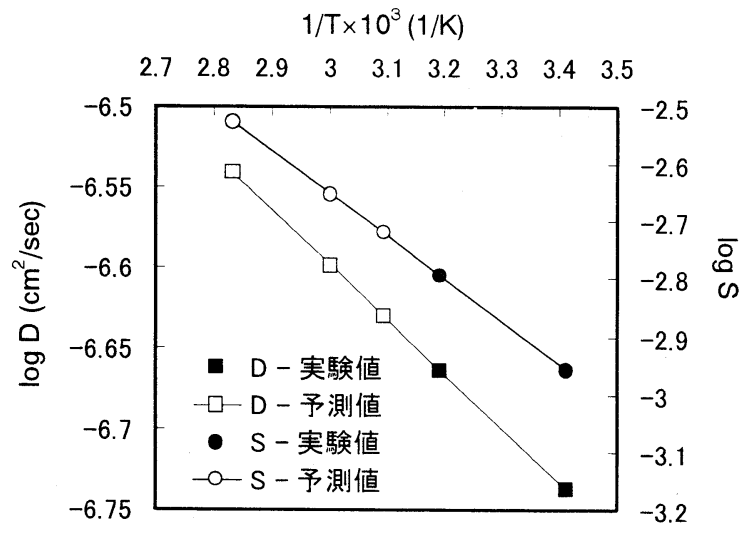

図-17 解析の条件

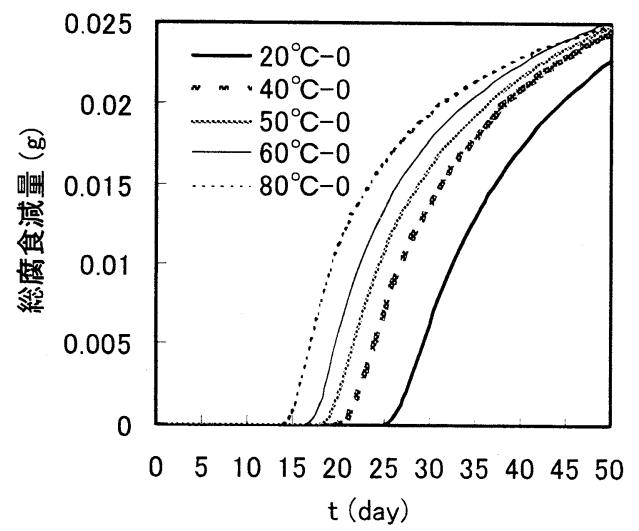

図-18 腐食減量の経時変化 (解析值)
ら離れた箇所はアノードとなり，初期と比較して反応速 度は非常に緩やかだが腐食を開始することが分かる。式 （７）に示した塩化物イオンと自然電位の関係の平均值は 図－14のように表せるが，本研究で用いた電流量は, 結局, 塩化物イオン濃度差の影響を表すものである。式 (7) から求められる自然電位は, 塩化物イオンが低濃度 であるほど自然電池の変動が大きく，高濃度になるほど 電位変化は停滞する傾向を見せる。

図一15は同一モデルにおける塩化物イオン濃度の分 布予測である。促進28日後の濃度分布予測では，鉄筋 位置（開放面からの高さ $2 \mathrm{~cm}$ ，図中矢印）にお海化 物イオン濃度はどの点においても $1 \%$ 以下となっている が，その程度の濃度の場合，図一14に示すように自然 電位の変働は激しい。つまり，自然電位差から生じる起 電力は大きくなる。その後, 促進 1 年後の濃度分布予測 ではかぶり全体で高濃度となっているが，この場合，自 然電位差は初期ほどには生じないことが図一 13 より分 かる。即ち，塩化物イオン濃度分布の不均衡はマクロセ ル腐食の主要な起電力であるという可能性が考えられ る。以上より，塩害環境下にあるひび割れを有する鉄筋 コンクリートの腐食速度は，塩化物イオンの浸透が長期 に及ぶ場合，鉄筋位置およびコンクリート全体で塩化物 イオン濃度に差が無くなり起電力が生じ難くなるために 減衰していくと考えられる。しかし実環境においては, 腐食量の増加により縦ひび割れが発生するためさらに塩 化物イオンが侵入しやすくなり，濃度差による起電力が 継続されることは充分考えられる。

\section{4 環境温度が鉄筋腐食に与える影響}

環境温度が異なる場合, 図一 16 に示す様に, 実験結 果ではいずれのひび割れ幅においても環境温度が高いほ ど腐食面積は大きくなる傾向が見られた。腐食現象にお いて作用する塩化物イオン濃度の環境温度による影響 を，ひび割れが存在しないと設定した解析モデルを用い て検討を行った。塩化物イオン拡散係数 Dおよび表面塩 分量係数 Sは温度に依存するという実験結果より，解析 值には促進 13 週, 環境温度 $20^{\circ} \mathrm{C}$ おび $40{ }^{\circ} \mathrm{C}$ 供試体より 得られた両値を用い，式( 5 )に示される予測式からその 他の環境温度における各係数を求めた。これは図一 17 
の様に表せる。

図一18に解析より得られた各環境温度における腐食 減量の初期経時変化を示す。前述のように，塩化物イオ ンは環境温度が高いほど拡散係数が大きくなるため鉄筋 に早く到達することとなり，腐食開始時期は早くなる。 しかし，その後は腐食減量の温度毎の差異は見られない 結果となった。これは, 腐食現象において塩化物イオン の働きのみを考える場合, 環境温度が高いほど早時期に かぶり全体で高濃度となるために電位差が初期ほどに生 じず，従って腐食起電力が弱まる可能性があるというこ とを示している。

化学反応からいえば，腐食速度は温度とともに増加す ることとなるが，実際には腐食速度に及ぼす温度の影響 はそれほど簡単には決まらない。例えば，溶存酸素のあ る水中での $\mathrm{Fe}$ の腐食速度は温度の上昇によって増加す る。しかし, 温度上昇に伴って拡散は促進されるが, 溶 存酸素の溶解度は減少する ${ }^{11)}$ 。本研究では, 酸素・水等 が腐食に与える影響は一定であると仮定して，塩化物イ オンの拡散のみに注目した場合, 特に腐食反応初期にお いて拡散係数の温度依存性からくる環境温度による影響 が顕著に現れることを解析により示すことができた。腐 食速度は各腐食因子の供給とバランスによって刻々と変 化するものであり, 塩化物イオンの濃度差のみでは腐食 現象は表せない。しかし, ひび割れが存在する場合の塩 害劣化のメカニズムの中で, 塩化物イオンがどの様に作 用するか解析的に検討することができたと考える。

\section{5. 結 論}

ひび割れを有する鉄筋コンクリート中の塩化物イオン 拡散浸透および鋼材腐食について, 本研究より得られた 結果を以下にまとめる。

（1）塩化物イオン拡散性状は温度依存性を有し，ア レニウス式を用いた予測が可能である。

（2）ひび割れからの塩化物イオンの見掛けの拡散を 考える場合，境界条件は開放面以外にひび割れ部にも与 える必要がある。

（3）ひび割れ部の境界条件となる表面塩分量は開放 面におけるひび割れ幅よりも環境温度に影響を受け，開 放面からの距離の平方根と直線関係で表せる。
（4）腐食因子の中で特に塩化物イオンの働きについ て考える場合，ひび割れの存在によって生じる塩化物イ オンの濃度差は起電力となり, それは特に腐食初期に大 きく作用する。

（5）腐食因子の中で得に塩化物イオンの働きについ て考える場合，腐食反応初期において環境温度による影 響が顕著に現れる。

[謝辞］本研究の一部は日本スパンクリート協会研究 助成金により行われたことを付記し，ここに謝意を表し ます。また，本研究を実施するにあたりご協力頂いた東 京大学生産技術研究所魚本研究室助手 加藤佳孝氏，同 技術官 星野富夫氏，芝浦工業大学卒業生 中山直基君 に深く感謝致します。

\section{参 考 文 献}

1）日本コンクリート工学協会：コンクリート構造物の腐食· 防食に関する試験方法ならびに基準（案），1987

2 ）小山理恵, 矢島哲司, 魚本健人, 星野富夫：自然電位を用 いた鉄筋腐食状態の推定手法に関する基礎的研究, 土木学 会論文集，No.550/V-33, pp.13-22, 1996.11

3 ）枅田佳寞, 天沼邦一, 吉崎芳郎, 御所窪邦男 : コンクリー トの乾湿にともなう塩化物の移動について，コンクリート 工学年次論文報告集, Vol.14, No.1, pp.787-792

4) 丸屋剛, 宇治公隆：コンクリートへの塩分の拡散浸透に関 する表面塩分量の定式化，コンクリート工学年次論文報告 集, Vol.11, No.1, pp.597-602, 1989

5）勝木太：コンクリート用各種繊維補強材の耐アルカリ性評 価に関する研究，東京大学学位論文，1997

6）森永繁：鉄筋の腐食速度に基づいた鉄筋コンクリート構造 物の寿命予測に関する研究，東京大学学位論文，1986

7）大即信明, 宮里心一，柴田常德，久田真，Tarek Uddin Md., 長㴰重義：鉄筋コンクリートの曲げひび割れ部に生じる腐 食の形成機構に及ぼす水セメント比の影響, 土木学会論文 集，No.606/V-41, pp.63-73, 1998.11

8）杉山隆文，長岡覚，橋本親典，辻幸和：コンクリートの塩 化物イオン拡散係数の経年変化を考慮したシミュレーショ ン解析の一例，セメントコンクリートの反応モデル解析に 関するシンポジウム論文集，pp.53-58, 1996.5

9）濱田秀則, Swamy, R.N. : 種々の海洋環境下に扔けるコン クリート中への塩化物イオン浸透過程および浸入量に関す る一考察，コンクリート工学論文集, Vol.7, No.1, pp.11-22, 1996

10）日本コンクリート工学協会：コンクリート構造物の補修工 法研究委員会報告書, 1996

11）伊藤伍郎：腐食化学と防食技術，コロナ社，1969.2

（原稿受理年月日：1999年 5 月 10 日） 
A Study on Corrosion Rate of Reinforcing Steel Bars in Cracked Concrete

By Ema TSUKAHARA and Taketo UOMOTO

Concrete Research and Technology, Vol.11, No.1, Jan. 2000

Synopsis Reinforced concrete is an excellent composite system combining both steel and concrete However, when a crack is formed in concrete both water and oxygen can easily approach to the surface of steel in concrete, and this causes corrosion of steel reinforcement The corrosion reduces the performance of reinforced concrete structure. This paper aims to evaluate the corrosion rate of steel in concrete quantitatively, in chloride environment The results show that corrosion rate of reinforcing steel bar can be predicted numerically by applying different chloride boundary conditions to cracked portion and other surfaces. The effect of temperature is also examined by both experiment and computer simulation

Keywords : cracked concrete, chloride diffusion, boundary condition, corrosion, natural potential, environmental temperature 